Megan Loumagne Boston College

School of Theology and Ministry

\title{
Dis-membering and Re-membering: The Eucharist and the Suffering of Women
}

\begin{abstract}
God desires wholeness for humanity, as well as freedom from all that dehumanizes and degrades. The Church represents the historical mediation of God's healing presence to the world, and as such, it stands in opposition against all that enslaves humanity. The Eucharist, in particular, is a salve to the suffering of human persons. Additionally, in its expression of embodiment and relationality, the Eucharist has special relevance for women. ${ }^{l}$ Yet the feelings of hope and comfort found in the ritual of the Eucharist are, for many women, diminished by other feelings of alienation and isolation invoked by this ritual. Thus the Eucharist exists as a source of contradiction and tension for many Catholic women, and to the extent that the ritual celebration of the Eucharist perpetuates the dehumanization of women, it obfuscates the good news of the gospel and presents an area of needed conversion within the Church. The purpose of this paper is to draw from the resources of both sacramental theology and theological anthropology to explore the relationship between the Eucharist and the suffering of women. It is only by listening attentively to the world, and especially to those who have suffered from the world's injustices, that the Church will be able to provide credible hope for humanity.
\end{abstract}

\section{Introduction}

"Desire for the humanity of humankind, for our soundness and wholeness, is something which is close to the heart of God, and not a reduction of the gospel.",2 --Edward Schillebeeckx

As Edward Schillebeeckx notes, God desires wholeness for humanity, as well as freedom from all that dehumanizes and degrades. Furthermore, the Church represents the historical mediation of God's healing presence to the world, and as such, it stands in opposition to all that enslaves humanity. The Eucharist, in particular, is a salve to human suffering. As John Baldovin S.J. notes, "the Eucharist is intended to be an experience of Christian hope."3 Additionally, in its

\footnotetext{
${ }^{1}$ Susan Ross notes in Extravagant Affections (Continuum; New York, 1998, 167) that embodiment and relationality are "two guiding principles of feminist theology" because of their high level of importance for women.

${ }^{2}$ Edward Schillebeeckx. The Understanding of Faith: Interpretation and Criticism, trans. N.D. Smith, (New York; Seabury Press, 1974), 132.

${ }^{3}$ John Baldovin, S.J. "Pignus Futurae Gloriae: Liturgy, Eschatology, and Hope," in Hope: Promise, Possibility, and Fulfillment, eds. Richard Lennan and Nancy Pineda-Madrid. (Mahwah, NJ: Paulist Press, 2013), 147.
} 
expression of embodiment and relationality, the Eucharist has particular relevance for women. ${ }^{4}$ Yet the feelings of hope and comfort found in the ritual of the Eucharist are, for many women, diminished by other feelings of alienation and isolation invoked by this ritual. Thus the Eucharist exists as a site of contradiction and tension for many Catholic women, and to the extent that the ritual celebration of the Eucharist perpetuates the dehumanization of women, it obfuscates the good news of the gospel and presents an area of needed conversion within the Church. As Schillebeeckx argues, the fundamental mission of the Church is the building up of humanity, and thus, "any praxis which manipulates human freedom and brings about alienation is both wrong and heterodox.",

The purpose of this paper is to draw from the resources of both sacramental theology and theological anthropology to explore the relationship between the Eucharist and the suffering of women. It must be noted from the outset that a project like this is fraught with challenges and limitations. Speaking of women as a monolithic category implies a universality to women's experiences that is non-existent, ${ }^{6}$ and furthermore, this type of project runs the risk of descending into what Sarah Coakley describes as "victimology," or theology that focuses on women's historical victimization to such an extent that it fails to account for other important elements of women's experiences in the world. ${ }^{7}$ Yet, despite the difficulties and liabilities inherent to it, articulating women's experiences—-both positive and negative — in the Church can provide an important data source for the Church as it seeks to articulate the gospel in a meaningful way in the twenty-first century. As Ann O'Hara Graff notes, "the very distortions themselves [inherent

\footnotetext{
${ }^{4}$ Susan Ross notes in Extravagant Affections (Continuum; New York, 1998, 167) that embodiment and relationality are "two guiding principles of feminist theology" because of their high level of importance for women.

${ }^{5}$ Schillebeeckx, The Understanding of Faith, 132.

${ }^{6}$ Ross, Extravagant Affections, 11.

${ }^{7}$ Sarah Coakley. Powers and Submissions: Spirituality, Philosophy and Gender, (Malden, MA: Blackwell Publishing, 2000), 33.
} 
in naming women's experiences], the way women have internalized them, and the ways women have struggled with them are part of the experiences we are seeking to grasp." ${ }^{\prime 8}$ It is only by listening attentively to the world, and especially to those who have suffered from the world's injustices, that the Church will be able to provide credible hope for humanity.

\title{
The Eucharist: Re-membering of the Broken Body of Christ ${ }^{9}$
}

\author{
"The Eucharist is the source \\ and summit of the Christian life."10 \\ --Catechism of the Catholic Church
}

While the Spirit of God pervades all that exists, sacraments are privileged means by which God communicates God's life to the world. ${ }^{11}$ Catholic Christians specifically affirm the "real presence" of Jesus Christ in the Eucharistic species (bread and wine), meaning, "In the most blessed sacrament of the Eucharist, 'the body and blood, together with the soul and divinity, of our Lord Jesus Christ and, therefore, the whole Christ is truly, really, and substantially contained."'"12 Catholics assert that the Eucharist is a sacramental encounter with the transcendent God who became incarnate in Jesus. This encounter is transformative for the individual and the community. The Eucharist plays a multi-faceted role in the Church as gift, task, symbol, and ritual. The Church's focus on the Eucharist was strengthened by the Second Vatican Council, which declared in its "Decree on the Ministry and Life of Priests" (Presbyterorum Ordinis), "The Most Blessed Eucharist contains the entire spiritual boon of the Church, that is, Christ Himself, our Pasch and Living Bread by the action of the Holy Spirit

\footnotetext{
${ }^{8}$ Ann O'Hara Graff, "The Struggle to Name Women's Experience," in In the Embrace of God: Feminist Theological Anthropology, (Maryknoll, NY: Orbis, 1995), 77.

${ }^{9}$ The use of "re-membering" was inspired by William Cavanaugh's book: Torture and Eucharist: Theology, Politics, and the Body of Christ, (Oxford: Blackwell, 1998), 229.

${ }^{10}$ Catechism of the Catholic Church, \$1324, accessed December 11, 2013, http://www.vatican.va/archive/ccc_css/archive/catechism/p2s2c1a3.htm.

${ }^{11}$ As Liam Bergin notes, sacraments are "ritual actions of the Church, the Spirit-filled community of faith, that derive from the ministry of Jesus Christ, the Eschatological Prophet, and of his saving proclamation of the kingdom of God and his Father" (Class handout. Boston College School of Theology and Ministry, December 11, 2013).

${ }^{12}$ Catechism of the Catholic Church, $\$ 1374$.
} 
through his very flesh vital and vitalizing, giving life to men [sic]." ${ }^{13}$ The Eucharist holds a privileged place in the hearts and minds of Catholics.

A distinction must be noted between Eucharistic theology and the ritual celebration of the Eucharist that occurs in the Catholic Mass. While ideally there would be continuity and consistency between the two, as with all human endeavors, there are often gaps between the ideal and the reality, and these gaps shift with the evolution of human culture. Identifying the gaps is the first step to bridging them. As Schillebeeckx notes, "the Church continually reinterprets, in groping fidelity, the unique message of salvation in every new socio-cultural situation." ${ }^{14}$ While the heart of the Gospel message remains constant, the historical mediation of that message must be renewed and adapted in order to continue to be meaningful for people. A ritual practice of the Eucharistic celebration attuned to the current cultural milieu will provide a more credible witness to the hope of the Gospel, for "religious language of faith becomes empty and meaningless unless it contains a recognizable reference to real human experiences and the autonomous structures implied in them." ${ }^{15}$ This "summit and source of Christian life" is full of "inexhaustible riches, ${ }^{, 16}$ and has been considered in multi-faceted ways by theologians throughout the history of the Church. Understanding the varied ways in which the Church has understood the Eucharist throughout its history will be useful in an evaluation of its meaning for the suffering of women in the contemporary age.

One of the most pervasive ways theologians have spoken of the Eucharist is as a means of incorporating humanity into the life of God. As St. Irenaeus notes, "For by no other means

\footnotetext{
${ }^{13}$ Presbyterorum Ordinis, §5, accessed on December 11, 2013, http://www.vatican.va/archive/hist_councils/ii_vatican_council/documents/vat-ii_decree_19651207_presbyterorumordinis_en.html.

${ }^{14}$ Edward Schillebeeckx, God, the Future of Man, trans. N.D. Smith, (New York: Sheed \& Ward, 1968$), 125$.

${ }^{15}$ Edward Schillebeeckx, Church: The Human Story of God, (New York: Crossroad, 1990), 211.

${ }^{16}$ Catechism of the Catholic Church, $\$ 1328$.
} 
could we have attained to incorruptibility and immortality, unless we had been united to incorruptibility and immortality." ${ }^{17}$ For Irenaeus, salvation is union with God, and therefore, the Eucharist is a central part of the Christian life because it facilitates that union. For Irenaeus, through the Incarnation, divinity and humanity are united in Christ, and through the Eucharist, "the substance of our flesh is increased and supported ... is nourished from the body and blood of the Lord, and is a member of Him." ${ }^{18}$ Christ became united to humanity through the Incarnation, humanity is united to Christ through the Eucharist, and this union is the salvation of humanity. Nicholas Cabasilas, a Greek Orthodox theologian, echoes this idea when he says, "He [Christ] both united our nature to Himself through the flesh which he assumed, and also united each one of us to his own flesh by the power of the mysteries." ${ }^{19}$ This statement is consistent with the Catechism of the Catholic Church.$^{20}$ The notion of the Eucharist as a means of union with God is a prominent understanding of the sacrament in the tradition and presents a great source of consolation for Christians in contemporary culture.

Another way of describing the Eucharist is as solidarity with the Paschal Mystery. In this way, the Eucharist is oriented to the past and makes the past perpetually present. As Hans Urs von Balthasar notes, "the Cross of Christ" is "indissolubly connected with his Eucharist." ${ }^{21}$ In the Eucharist, the believer enters into the life of the God who assumed humanity's condition with all of its heartache, and who was tortured, abandoned, and brutally killed. As Georges Florovsky notes, “The Sacraments are instituted in order to enable man to participate in Christ's redeeming

\footnotetext{
${ }_{17}^{17}$ Irenaeus, Against Heresies, accessed December 14, 2013, http://www.newadvent.org/fathers/0103319.htm. III. 19.

18 Ibid., V.II.3.

${ }^{19}$ Nicholas Cabasilas, The Life in Christ, (New York: St. Vladimir's Seminary Press, 1974), 54.

${ }^{20}$ Catechism of the Catholic Church, $\$ 1382$.

${ }^{21}$ Hans Urs Von Balthasar, Theo-Drama: Theological Dramatic Theory, Volume IV: The Action, trans. Graham Harrison, (San Francisco: Ignatius Press, 1994), 379.
} 
death ..."22 One enters into the life of God only through the Cross. The Eucharist thus initiates union with God through the solidarity with the passion of Christ. Yet while the Eucharist draws us into solidarity with the suffering, tortured, abandoned Christ, it is not only an encounter with the suffering Christ. Rather, it is union with the suffering Christ so as "to gain the grace of his resurrection. ${ }^{23}$ This encounter with the suffering Christ in the Eucharist must always be oriented toward the "sacramental anticipation, a foretaste of the resurrection." 24 All sacraments flow from the ministry of Jesus Christ, the "Eschatological Prophet," 25 and thus are oriented to both past and future, and this is especially true of the Eucharist because of the Christological nature of the sacrament. As William Cavanaugh notes, "[the Eucharist] recalls more than the past events of Jesus' life, death, and resurrection, but also expresses ardent longing for the future completion of the Kingdom Christ inaugurated. ${ }^{26}$ In the Eucharist, the believer joins in solidarity with the both the suffering and the glorified Christ who enables all who are united with him to share in his glorified life. ${ }^{27}$

In addition to conceptualizing the Eucharist as union with God and solidarity with the Paschal Mystery of Jesus, another frequently used motif to explain the Eucharist is that of the "sacrifice" or "self-emptying" of Jesus. This stems from the letter to the Philippians in the New Testament, which declares that Christ through his suffering and death "emptied himself, taking the form of a slave." ${ }^{28}$ Christ's death was the ultimate act of sacrificial love. The ritual of the Eucharist re-presents the original sacrifice of Christ. As the Catechism explains, "The sacrifice

\footnotetext{
${ }^{22}$ Georges Florovsky, "Redemption," in The Collected Works of Georges Florovsky, Vol III.: Creation and Redemption, (Belmont, MA: Nordland Publishing Company, 1976), 56.

${ }^{23}$ Ibid.

${ }^{24}$ Florovsky, "Redemption," 59.

${ }^{25}$ Bergin, class handout.

${ }^{26}$ William Cavanaugh, Torture and Eucharist, 226.

${ }^{27}$ David N. Power, O.M.I, The Eucharistic Mystery: Revitalizing the Tradition, (New York: Crossroad, 1992), 295.

${ }^{28}$ Philippians 2:7. The New American Bible.
} 
of Christ and the sacrifice of the Eucharist are one single sacrifice." ${ }^{29}$ The language of sacrifice is also common in the early Church fathers. For example, Augustine declares in The City of God that the Eucharist "has succeeded all the sacrifices of the Old Testament, which were slain as a shadow of what was to come... Because, instead of all these sacrifices and oblations, his body is offered and is served up to the partakers of it." ${ }^{\prime 30}$ This motif is prominent in Scripture and in the writings of the tradition, and is commonly used by contemporary theologians to explain the Eucharist. Monika Hellwig affirms, "When we celebrate Eucharist, we do indeed participate in the sacrifice of Jesus," ${ }^{\prime 31}$ and William Cavanaugh declares that the Eucharist is "a knitting together of the body of Christ by the participation of many in His sacrifice." ${ }^{\prime 2}$ While these motifs of the Eucharist as sacrifice and kenosis are prominent in Scripture and in the writings of the tradition, this is not without controversy and requires careful nuance, as will be discussed below.

A final motif to mention regarding the Eucharist is the notion of Eucharist as memorial. The gospel of Luke describes Christ commanding the disciples to consume the bread and wine "in remembrance" ${ }^{" 33}$ of him. When the community gathers around the Eucharistic table, it is as Cavanaugh describes, a "remembering of Jesus' own torture at the hands of the powers of the world. ${ }^{, 34}$ However, this remembrance is not a grim fixation upon a past event, but rather the memorial of Christ's death and resurrection is an "anticipative memory"35 and "a literal remembering of Christ's body. ${ }^{{ }^{36}}$ Thus this memorial of the suffering, death, and resurrection of Jesus is always oriented to the future and is transformative for the people of God.

\footnotetext{
${ }^{29}$ Catechism of the Catholic Church, §1367.

${ }^{30}$ Augustine, The City of God, 17.20, accessed on December 11, 2013, http://www.newadvent.org/fathers/120117.htm.

${ }^{31}$ Monika Hellwig, The Eucharist and the Hunger of the World, (New York: Paulist Press, 1976), 76.

${ }^{32}$ Cavanaugh, Torture and Eucharist, 229.

${ }^{33}$ Luke 22:19, New American Bible.

${ }^{34}$ Cavanaugh, Torture and Eucharist, 2.

${ }^{35}$ Power, The Eucharistic Mystery, 315.

${ }^{36}$ Cavanaugh, Torture and Eucharist, 229.
} 


\section{The Suffering of Women: Dis-membering and Disappearing}

"Suffering is the greatest challenge to our belief in the goodness of creation and the possibility of salvation." 37

--Kathleen McManus

In contrast to the hope offered by the gospel of Christ and the Eucharist, human suffering scandalizes and destroys the human spirit. ${ }^{38}$ Suffering is "the alpha and omega of the whole history of mankind; it is the scarlet thread by which this historical fragment is recognizable as human history: history is 'an ecumene of suffering." ${ }^{39}$ Not all suffering is meaningless, and there is suffering that gives birth to beauty and progress. Yet, the ubiquity of senseless destruction, abuse, oppression, exploitation, injustice, and poverty present in the world defies the ability of theologians "to give an ethical, hermeneutical and ontological analysis of our disaster." ${ }^{40}$ There is a "barbarous excess" ${ }^{41}$ of suffering in the world that confounds rational explanation. Suffering easily overwhelms the human spirit and poses a significant challenge to the possibility of hope rather than despair as a fundamental orientation to the world.

Physician Eric Cassell offers a helpful nuance regarding a definition of suffering in his suggestion that the primary characteristic of human suffering is "the state of severe distress associated with events that threaten the intactness of the person." ${ }^{\text {"42 }}$ The primary threat of suffering to the human spirit is that of disintegration, or trauma to the centered self. Thus, human suffering is antithetical to the telos of Christianity, which is union with God and the "soundness

\footnotetext{
${ }^{37}$ Kathleen McManus, "Suffering in the Theology of Edward Schillebeeckx," Theological Studies 60.3 (1999), 476.

${ }^{38}$ For this purposes of this paper, when I speak of "suffering" I am primarily referring to unjust suffering (as opposed to suffering as a result of a crime committed, etc.) and suffering that has not been freely chosen by the human subject. Of course, the distinctions between these "types" of sufferings are not clean cut, but must be made for practical considerations of time and space.

${ }^{39}$ Edward Schillebeeckx, Christ, The Experience of Jesus as Lord, (New York; Seabury Press, 1980), 725.

${ }^{40}$ Schillebeeckx, Christ, 725.

${ }^{41}$ Ibid.

${ }^{42}$ As quoted by Patricia Wismer in "For Women in Pain: A Feminist Theology of Suffering," in In the Embrace of God, 140 .
} 
and wholeness ${ }^{\$ 3}$ of humanity. Furthermore, as human beings exist in an intrinsically interconnected way with the rest of creation, the disintegration and destruction in human suffering is also harmful to the greater human community and the natural world. As John R. Sachs, S.J. notes, "each individual life is the life of the whole and vice-versa." ${ }^{44}$ The suffering of every human is the concern of Christ, the Church, and the world.

Before discussing the particular suffering of women, it is important to mention contributions from the theory of evolution to this topic of suffering. Evolutionary theory has demonstrated that the existence of suffering cannot be completely attributed to human sin. Rather, "thousands of centuries before a thinking being appeared on our earth, life swarmed on it, with its instincts and its passions, its sufferings and its deaths. ${ }^{{ }^{45}}$ Thus, a certain amount of suffering exists as necessary and natural for the growth and progress of the world. Yet, completely attributing human suffering to evolutionary inevitability remains an unsatisfactory response because it cheapens both human suffering and human freedom. ${ }^{46}$ Especially in light of the horror of the world wars, evolution as an rationalization for human suffering is unacceptable. While there is certainly suffering that is a "natural" part of living in an evolving world, there is much unnecessary suffering that is only a result of acts of human freedom. Rather than provide an explanation for the mystery of evil and suffering, Christianity must acknowledge that "suffering remains impenetrable and incomprehensible, and provokes rebellion." ${ }^{47}$ In light of the scandal of human suffering, there exists a moral imperative to use all of the resources of human freedom to rebel against unjust and unnecessary human suffering.

\footnotetext{
${ }^{43}$ Schillebeeckx, Church, 131.

${ }^{44}$ John R. Sachs, S.J, The Christian Vision of Humanity: Basic Christian Anthropology, (Collegeville, MN, Liturgical Press, 1991), 37.

${ }^{45}$ Pierre Teilhard de Chardin, Christianity and Evolution, (New York; Harcourt Brace, 1971), 38.

${ }^{46}$ Karl Rahner, "Why Does God Allow Us to Suffer?", in Theological Investigations, 19, (New York: Crossroad, 1983), 199.

${ }^{47}$ Schillebeeckx, Christ, 728.
} 
From a consideration of human suffering in general, this paper now turns to the suffering of women in particular. A brief summary from Elizabeth Johnson provides a helpful perspective. She notes,

While comprising $1 / 2$ of the world's population, women do $3 / 4$ of the world's work; receive $1 / 10$ of the world's salary; own $1 / 100$ of the world's land; form $2 / 3$ of illiterate adults; and together with their dependent children are $3 / 4$ of the world's starving people. In addition, women are raped, beaten, prostituted, and murdered by men to an extent that is not mutual. ${ }^{48}$

Additionally, Ann O’Hara Graff notes the "deeply troubling fact of violence against women"49 that has been "so internalized by women that we have become violators of ourselves and others." ${ }^{50}$ She describes the violence as both "domestic and social," including "rape, wife battering, incest, child abuse. . [and the fact that] women are the poorest and the most numerous of the poor. ${ }^{, 51}$ These facts rightly evoke acts of protest, including theological pursuits of a more dignified destiny for women in the world.

Acknowledging the broader context of the disintegration, disappearance, and dismemberment (both metaphorical and literal) of women around the world, this paper focuses specifically on the suffering of women in religious contexts, and then on the ritual of the Eucharist in the Catholic mass. To do this, I use a concept articulated by Mary Farrell Bednarowski, a Professor of Religious Studies at United Theological Seminary. While she is admittedly not a theologian, her sociological approach offers helpful resources for this paper. In her book, The Religious Imagination of American Women, Bednarowski develops a concept she labels "ambivalence" as an umbrella term to depict contemporary women's religious experience

\footnotetext{
${ }^{48}$ Elizabeth Johnson, "Forging Theology: A Conversation with Colleagues," in Things New and Old: Essays on the Theology of Elizabeth A. Johnson, eds. Phyllis Zagano and Terrence W. Tilley (New York: Crossroad, 1999), 91.

${ }^{49}$ Graff, "Women's Experience," 82.

${ }^{50}$ Ibid.

${ }^{51}$ Ibid.
} 
in the United States. While ambivalence often carries the connotation of apathy or a lack of feeling, Bednarowski rejects this definition in favor of an interpretation of ambivalence as deeply rooted in powerful but contradictory feelings. She describes the ambivalence of women's religious experience as, "grounded in a deep sense of belonging, familiarity, and commitment and an equally strong sense of alienation and distrust." ${ }^{, 52}$ Ambivalence for Bednarowski is not a dearth of feeling, but the navigation of an excess of strong feelings.

Bednarowski argues that humans participate in religion through their gender, and thus women experience religion differently than men. ${ }^{53}$ The main source of difference between women's experience and men's experience in religion lies in the fact that "women have been excluded from the histories of their traditions and from having a voice in the theological formulation of their traditions. ${ }^{{ }^{54}}$ While women tend to be highly participatory in religions, more so than men, this participation has been in "more private ways that have been unacknowledged and undervalued and must be recovered. ${ }^{\prime 55}$ Because women are often the most involved in "behind the scenes" religious practice and devotion, but then are frequently excluded from a public presence or significant positions of leadership, this leads to their sense that they are both insiders and outsiders within the religion, which is the foundation of Bednarowski's theory regarding ambivalence. ${ }^{56}$ Bednarowski contends that rather than a "vice to be avoided," ${ }^{57}$ ambivalence is a "virtue to be cultivated in creative and dynamic ways. ${ }^{158}$ She argues that the unique position of women as both insiders and outsiders within religious traditions offers women a privileged place of perspective that can be channeled into a "creativity that flourishes on the

\footnotetext{
${ }^{52}$ Mary Farrell Bednarowski, The Religious Imagination of American Women, (Bloomington, IN: Indiana University Press, 1999), 19.

${ }_{54}^{53}$ Bednarowski, The Religious Imagination, 4.

${ }^{54}$ Ibid.

${ }^{55}$ Ibid.

${ }^{56}$ Ibid., 17.

${ }^{57}$ Ibid., 20.

${ }^{58}$ Ibid.
} 
margins without losing sight of the center." ${ }^{\text {99 }}$ The position of women as "insiders" cultivates emotional attachment to and deep familiarity with the religion, while the position of women as "outsiders" facilitates a "critical distance" between women and the tradition that allows women a clearer perspective. According to Bednarowski, the tension between these positions is the birthplace of creativity.

While Bednarowski's notion of ambivalence is a useful frame for understanding contemporary women's religious experience in the United States, I cannot agree with her optimism regarding ambivalence. While it may be true that the awkward position of women as simultaneously insiders and outsiders in a religious tradition can be integrated in creative ways by women, describing ambivalence as a "virtue to be cultivated" minimizes the significant suffering that accompanies the experience of exclusion. If part of the experience of ambivalence is one of a "strong sense of alienation and distrust, ${ }^{160}$ how can this be something that women ought to cultivate? Ambivalence poses an obstacle to women's ability to achieve integration and unity within themselves, with the community, and with God. Additionally, to view ambivalence as a virtue is to excuse women from striving for more full participation in religions and in theological development, and furthermore, it excuses men from the responsibility of partnering with women to seek their greater inclusion. There are certainly benefits that a strong and virtuous soul can find in the experience of any suffering, including the suffering of ambivalence. However, as Bednarowski notes, the pain associated with this experience of ambivalence is often severe and includes feelings of "confusion and silence, invisibility and worthlessness, pain and betrayal" 61 that do not necessarily lead to accompanying feelings of "amazing hope and

\footnotetext{
${ }^{59}$ Ibid.

${ }^{60}$ Bednarowski, The Religious Imagination, 19.

${ }^{61}$ Ibid., 30 .
} 
renewal" ${ }^{62}$ as Bednarowski suggests. While there may be women who are able to channel the experience into something positive, the more likely outcome is that women will feel increasingly frustrated and leave, or will decide to stay in the religion while suffering from it. Both of these outcomes contradict the heart of the gospel as an invitation from the living God to freedom from oppression and dehumanization.

If ambivalence is common form of suffering among contemporary women in the United States in religions in general, this experience is particularly prevalent within the Catholic faith. As Susan Ross notes, the Catholic faith is "a tradition that both nurtures and alienates." 63 With only one of the sacraments specifically requiring the presence of a woman (the sacrament of marriage), it appears that in Catholic sacramental theology, women are "at best, a reluctant 'last resort' for liturgical functions." ${ }^{\prime 64}$ While the Second Vatican Council brought about great hope for women, and as Ross notes, "since the Second Vatican Council women have become involved in the church in increasingly visible ways, ${ }^{\prime 65}$ there remains a great deal of work to be done. Specifically, the Eucharist remains an ambiguous and ambivalent experience for women. With the Second Vatican Council's renewal of focus on the Eucharist, it "has, at its worst, become, unfortunately, a one-man show." ${ }^{66}$ While it is worth noting that there are many priests who do everything in their power to include women in every part of the Mass, there remain many priests who do not, and their exclusion of women is in many ways sanctioned by canon law ${ }^{67}$ Thus, the

\footnotetext{
${ }^{62}$ Ibid.

${ }^{63}$ Ross, Extravagant Affections, 10.

${ }^{64}$ Ross, Extravagant Affections, 27. It is worth noting that while this is the case based on canon law and Catholic sacramental theology, there is a significant gap between the denominational policy and the practice within many parishes. Mark Chaves establishes this fact in his book, Ordaining Women: Culture and Conflict in Religious Organizations (Cambridge, MA: Harvard University Press, 1997).

${ }^{65}$ Ibid., 163.

${ }^{66}$ Ibid., 208.

${ }^{67}$ According to canon law, if clergy are available, lay men and women ought not to serve as Eucharistic ministers. While this law is often overlooked in the practical experiences parish life, the fact that (theologically unnecessary)
} 
Eucharist, "the source and summit of Christian life," exists as a site of confusion and conflict for women. Insofar as the ritual Eucharistic celebration alienates women, it presents an obstacle to the reception of the gospel.

\title{
The Eucharist and the Suffering of Women: Challenges and Possibilities
}

\author{
"I feel very strongly that it is better \\ that there should be no belief in eternal life \\ than that a God should be presented \\ who diminishes people. ${ }^{" 68}$ \\ --Edward Schillebeeckx
}

Eucharistic theology envisions the Eucharist as a sacramental sign of unity that opposes the alienation, isolation, and fragmentation of the Christian faithful. The Eucharist both demands and enables the unity it signifies. It is meant to be transformative for the people of God. As William Cavanaugh notes, "In the Eucharist the church is always called to become what it eschatologically is ... Christians are called to conform their practice to the Eucharistic imagination." Indeed, the Eucharist "disrupts the imagination of violence." ${ }^{\prime 69}$ While the suffering of humanity disrupts, destroys, destabilizes, and disintegrates the human spirit, the Eucharist symbolizes and produces unity, solidarity, hope, and wholeness. In light of the telos of the Eucharist, the suffering of women characterized by ambivalence is an unacceptable reality in need of healing. Christ invites all the baptized into the life of God through the Eucharist. Alienation, isolation, betrayal, invisibility, and feelings of worthlessness are antithetical to the love of Christ found in the Eucharist. As Tissa Balasuriya notes, "The Eucharist is spiritual food insofar as it leads to greater love, self-unity, and communion among persons and groups,"70 and

\footnotetext{
laws like this continue to exist hinders the full participation of the laity and facilitates a mindset that further contributes to the exclusion of women.

${ }^{68}$ Schillebeeckx, Church, 130.

${ }^{69}$ Cavanaugh, Torture and Eucharist, 206.

${ }^{70}$ Tissa Balasuriya, O.M.I., The Eucharist and Human Liberation, (Maryknoll, NY: Orbis, 1979), 22.
} 
"unless there is this twofold dimension of personal love and societal action, the Eucharist can be a sacrilege. ${ }^{\text {"11 }}$ While the Eucharist transcends the issue of women's full participation, it does not exclude it. The Eucharist has immediate implications for the just treatment of all people. While in an imperfect world there will always be factors that hinder our worship and communion with one another, it is incumbent upon the Church to remedy these obstacles. As Schillebeeckx notes, "We can say that a church which obscures its own truth, especially the liberating freedom of Jesus Christ, through the form of its authoritarian and hierarchical mediation, becomes an unattractive and abstract institution for believers." ${ }^{72}$ Thus, a Eucharistic celebration attuned to the current cultural milieu, while still maintaining continuity with the ancient tradition, will increase the possibility of the Eucharist being a source of hope. This paper will now juxtapose the various motifs described above for understanding the Eucharist with the reality of the suffering of women in order to note the possibilities and challenges facing the Church in this regard.

The notion of the Eucharist as a means of union with God presents a significant source of consolation for Christians in contemporary culture, and particularly for women. In a culture dominated by individualism and disembodied, digital modes of relating, anxiety and loneliness present significant obstacles to human flourishing. ${ }^{73}$ Feminist theologians note that connection and embodiment are particularly strong values for women. ${ }^{74}$ Thus, the Eucharist as a privileged place of bodily and spiritual connection with Jesus Christ and the Catholic community presents a significant source of solace and hope for the wounds inflicted upon women by contemporary society. Yet, the goal of union with Christ and the community through the Eucharist is severely hindered by the removal of female presence during the ritual. As Mary Collins states, "The

\footnotetext{
${ }^{71}$ Ibid.

${ }^{72}$ Schillebeeckx, Church, 214.

${ }^{73}$ Gary Badcock, The House Where God Lives: Renewing the Doctrine of the Church Today (Grand Rapids, MI: Eerdmans, 2009), 291.

${ }^{74}$ Ross, Extravagant Affections, 167.
} 
Sunday Eucharistic assembly has for centuries provided the ritual setting in which all lay Catholics learned that they were not clerics, learned the consequences of their lesser status, and learned about women's special deficiencies based on their sexual identity."${ }^{975}$ While there may have been women lectors or cantors at other points in the mass, at the holiest moment of the Mass - the consecration — women are pushed to the margins. This creates a confusing experience for women as they are pushed away from the consecration of the Eucharist, but then are invited to draw near to Christ through reception of the Eucharist. This repeated ritual shapes the consciousness of participants in the Mass, including the priest himself. This is not primarily a theological argument for the ordination of women, although there may be natural connections to that issue. Rather, it is an observation regarding the power of repeated ritual and symbol to inculcate beliefs about gender and identity to human persons. The Eucharist as symbolizing and effecting union with Christ and the Christian community remains full of possibility, but fraught with ambiguous and contradictory messages for women. Therefore, in many ways, it contributes to women's ambivalence as form of suffering.

The notion of the Eucharist as solidarity with the Paschal Mystery of Christ presents a significant source of healing for the suffering of humanity. According to Monika Hellwig, "The blessing with which he blesses us in the Eucharist is the invitation and the empowerment to enter into the experience with him in his death, and only from that experience of ultimate suffering and despair to enter into the hope that the Resurrection holds for the future history of the world." ${ }^{.76}$ To enter into the passion of Christ is to encounter Jesus who was betrayed, silenced, tortured, and abused. The Eucharist provides a means by which the suffering victims of the world can be reminded that they are not alone. However, the solidarity with the God who suffers with the

\footnotetext{
${ }^{75}$ Mary Collins, "The Refusal of Women in Clerical Circles," in Women in the Church, I., ed. Madonna Kolbenschlag, (Washington D.C.: Pastoral Press, 1987), 60.

${ }^{76}$ Hellwig, The Eucharist, 52.
} 
victims of human history found in the Eucharist moves beyond simply God's "being with" those who suffer. ${ }^{77}$ In the Eucharist, the suffering also participate in what was brought about by Christ's suffering — namely, resurrection. The Eucharist rebukes the finality of suffering, and reminds victims that pain and death will not ultimately triumph over love. As Schillebeeckx notes, "The Easter faith expresses the fact that murder — and therefore any form of evil—has no future." ${ }^{98}$ This conception of the Eucharist as solidarity with the passion of Christ presents many creative possibilities for the healing of women's suffering. One of these possibilities is that it may provide women with a space to lament. As Bradford Hinze notes, "lament expresses the pain of unfulfilled aspirations or intentions. ${ }^{.79}$ Understanding, acknowledging, and expressing pain is the beginning of healing. Additionally, lament is a form of protest that is creative rather than destructive. As Hinze argues, "the lamenter stands up to the others and calls into question destructive power dynamics by offering resistance and working to renegotiate the relations with authorities and along borders." ${ }^{80}$ The notion of the Eucharist as solidarity with the Paschal Mystery that is oriented toward eschatological hope and that allows for lament in the face of suffering is a useful conception of the Eucharist for the healing of women's suffering.

As mentioned above, the motif of the Eucharist as sacrifice and self-emptying is prominent in Scripture, the Catechism, and in the writings of the Catholic tradition. Many feminist theologians have rejected this conception altogether because of their belief that this presents Christianity as "an abusive theology that glorifies suffering." ${ }^{\prime 1}$ They express a legitimate fear that the centrality of the sacrificial death of Jesus will spiritualize the oppression of the

\footnotetext{
${ }^{77}$ Power, The Eucharistic Mystery, 62.

${ }^{78}$ Schillebeeckx, Church, 129.

${ }^{79}$ Bradford Hinze, "Ecclesial Impasse: What Can We Learn From Our Laments?" Theological Studies 72 (2011), 477.

${ }^{80}$ Ibid., 478-479.

${ }^{81}$ Joanne Carlson Brown and Rebecca Parker, "For God so Loved the World?" in Christianity, Patriarchy, and Abuse: A Feminist Critique, eds. Joanne Carlson Brown and Carole R. Bohn, (New York: Pilgrim Press, 1989), 27.
} 
vulnerable and encourage women to "submit to lives of self-destructive subordination."

However, rejecting these motifs eliminates a significant emphasis of the tradition and renders the Christian faith unrecognizable. If carefully nuanced, this concept of the Eucharist as sacrifice need not be abandoned in order to liberate the oppressed and contribute to the healing of women's suffering. For as Florovsky notes, "the whole significance of sacrifice is not the denial itself, but the sacrificial power of love." challenges for women, it can be redeemed. Sarah Coakley offers a helpful way forward in her description of sacrifice and kenosis as ways to "confront(s) issues of fragility, suffering, or 'selfemptying"” while avoiding "victimology." ${ }^{\text {" }}$

Coakley rightly argues that one can embrace vulnerability and the notion of sacrifice not in the sense of "asking for unnecessary and unjust suffering" or destroying one's self altogether. Rather, the self-emptying and sacrifice we participate in with Christ through the Eucharist is defined by the placing "of the self's transformation and expansion into God." ${ }^{15}$ This is liberating for women in that it allows women to become vulnerable to the one who is perfectly just and loving, and thereby to be cherished and strengthened. There is much more that could be said on the intersection of Eucharist as "kenotic sacrifice" and the flourishing of women, but it is enough to note that there are constructive options available that would allow for the retention of the central theme of the Eucharist as a sacrifice in a theology seeking to honor the experience of women and to contribute to the healing of women's suffering.

Finally, the understanding of the Eucharist as memorial is a powerful resource for the broken and suffering of the world. Rather than a disinterested gaze upon the past, the Eucharist is

\footnotetext{
${ }^{82}$ Coakley, Powers and Submissions, 4

${ }^{83}$ Florovsky, "Redemption," 37.

${ }^{84}$ Coakley, Powers and Submissions, 33.

${ }^{85}$ Ibid., 36.
} 
a dynamic, eschatological encounter in which, "In our presence, the Son of Man gathers up the remnants of our memories, the broken fragments of our histories, and judges, blesses, and transforms them. His Eucharistic banquet re-orders us, re-members us, restores us, and makes us one. ${ }^{86}$ In remembering the suffering, death, and resurrection of Christ, the Christian faithful are reminded that God remembers the suffering of God's people and will spare nothing in order to redeem them. Memorializing the passion of Christ is an act of protest against all oppression and abuses of power.

This act of remembrance celebrates the tortured body of Christ not as a means of masochism or glorification of suffering, but instead, as a reminder that what has been broken will be made whole again and that suffering will not have the last word. Therefore, this notion of Eucharist as memorial offers hope to women who have been "abused, commodified, prostituted, dehumanized, divinized, infantilized, pushed to the margins, silenced, made invisible." ${ }^{87}$ The broken body of Christ is not permanently broken. Rather, when his suffering was complete, "God greatly exalted him." ${ }^{88}$ As we remember the suffering and death of Christ, we remember his resurrection as well. The memorial of Christ "expresses ardent longing for the future completion of the Kingdom Christ inaugurated." ${ }^{89}$ The Eucharist as memorial directs the vision of the Christian faithful to that time when the shattered mirror into which we gaze will be put back together and we shall "know fully," even as we are "fully known."

\section{Conclusion}

\footnotetext{
${ }^{86}$ Shawn Copeland, Enfleshing Freedom: Body, Race, and Being, (Minneapolis: Fortress Press, 2010), 128.

${ }^{87}$ Taken from the introduction to this paper.

${ }^{88}$ Philippians 2:9. New American Bible.

${ }^{89}$ Cavanaugh, Torture and Eucharist, 226.

901 Corinthians 13:12. New American Bible.

${ }^{91}$ Schillebeeckx, God, the Future of Man, 136.
} 
The Church, when faithful to its identity, will be in a constant state of conversion. It must continually be open to renewal in light of the signs of the times. Yet, as Bednarowski notes, "a tradition does not need to be perfect in order to be compelling. ${ }^{\prime 92}$ Despite its imperfections and wounds, the Catholic Church and the sacrament of the Eucharist, in particular, continue to be compelling to humanity. Even for women, who continue to struggle with painful feelings of ambivalence, alienation, and isolation in a tradition they love, there are many resources within the Catholic faith and the Eucharist that offer hope and consolation. There is much work yet to be done to recover women's voices from the tradition's past, and to begin to listen to women's voices in the present. Yet the Eucharist stands as a symbol of hope that the toil toward a truly unified Church is not in vain. Indeed, this "literal re-membering of Christ's body, a knitting together of the body of Christ by the participation of many in His sacrifice" ${ }^{\prime 93}$ is a continual assault on all that would fragment and isolate. In the Eucharist we see that what looks like a situation of irreparable division and brokenness is not more powerful than the Spirit of God, who is able to "accomplish far more than all we ask or imagine."

\footnotetext{
${ }_{92}^{92}$ Bednarowski, The Religious Imagination, 41.

${ }^{93}$ Cavanaugh, Torture and Eucharist, 229.

${ }^{94}$ Ephesians 3:20. New American Bible.
} 


\section{Works Cited}

Augustine. The City of God. Accessed on December 11, 2013, http://www.newadvent.org/fathers/120117.htm.

Badcock, Gary. The House Where God Lives: Renewing the Doctrine of the Church Today. Grand Rapids, MI: Eerdmans, 2009.

Balasuriya, Tissa, O.M.I. The Eucharist and Human Liberation. Maryknoll, NY: Orbis, 1979.

Baldovin, John., S.J. “Pignus Futurae Gloriae: Liturgy, Eschatology, and Hope,” In Hope: Promise, Possibility, and Fulfillment, edited by Richard Lennan and Nancy Pineda-Madrid. New York: Paulist Press, 2013.

Bednarowski, Mary Farrell. The Religious Imagination of American Women. Bloomington, IN: Indiana University Press, 1999.

Bergin, Liam. Class handout. Boston College School of Theology and Ministry, December 11, 2013.

Brown, Joanne Carlson and Parker, Rebecca. "For God so Loved the World?" In Christianity, Patriarchy, and Abuse: A Feminist Critique. Edited by Joanne Carlson Brown and Carole R. Bohn. New York: Pilgrim Press, 1989.

Cabasilas, Nicholas. The Life in Christ. New York,: St. Vladimir's Seminary Press, 1974.

Catechism of the Catholic Church. Accessed on December 11, 2013, http://www.vatican.va/archive/ccc_css/archive/catechism/p2s2c1a3.htm.

Cavanaugh, William. Torture and Eucharist: Theology, Politics, and the Body of Christ, Oxford: Blackwell, 1998.

Chaves, Mark. Ordaining Women: Culture and Conflict in Religious Organizations. Cambridge, MA: Harvard University Press, 1997.

Coakley, Sarah. Powers and Submissions: Spirituality, Philosophy and Gender. Malden, MA: Blackwell Publishing, 2000.

Collins, Mary. "The Refusal of Women in Clerical Circles," In Women in the Church, I. Edited by Madonna Kolbenschlag. Washington DC: Pastoral Press, 1987.

Copeland, Shawn. Enfleshing Freedom: Body, Race, and Being. Minneapolis: Fortress Press, 2010.

De Chardin, Pierre Teilhard. Christianity and Evolution. New York: Harcourt Brace, 1971.

Florovsky, Georges. "Redemption," In The Collected Works of Georges Florovsky, Vol III:

Creation and Redemption. Belmont, MA: Nordland Publishing Company, 1976.

Graff, Ann O'Hara. “The Struggle to Name Women's Experience,” In In the Embrace of God:

Feminist Theological Anthropology, Edited by Ann O’ Hara Graff. Maryknoll, NY: Orbis, 1995. 
Hellwig, Monika. The Eucharist and the Hunger of the World. New York: Paulist Press, 1976.

Hinze, Bradford. "Ecclesial Impasse: What Can We Learn From Our Laments?" Theological Studies 72 (2011), 470-495.

Irenaeus, Against Heresies. Accessed December 14, 2013, http://www.newadvent.org/fathers/0103.htm.

Johnson, Elizabeth. "Forging Theology: A Conversation with Colleagues," In Things New and Old: Essays on the Theology of Elizabeth A. Johnson. Edited by Phyllis Zagano and Terrence W. Tilley. New York: Crossroad, 1999. Accessed on December 14, 2013, http://www.fordham.edu/academics/programs_at_fordham_/theology/faculty/elizabeth_a_johnson_/elizabe th_a_johnson__82888.asp.

McManus, Kathleen. "Suffering in the Theology of Edward Schillebeeckx," Theological Studies 60.3 (1999), 476-491.

New American Bible. Wichita, KS: Fireside Catholic Publishing, 2009.

Power, David N., O.M.I. The Eucharistic Mystery: Revitalizing the Tradition. New York: Crossroad, 1992.

Presbyterorum Ordinis, Accessed on December 11, 2013, http://www.vatican.va/archive/hist_councils/ii_vatican_council/documents/vatii_decree_19651207_presbyterorum-ordinis_en.html.

Rahner, Karl. "Why Does God Allow Us to Suffer?” In Theological Investigations 19. New York: Crossroad, 1983.

Ross, Susan. Extravagant Affections. New York: Continuum, 1998.

Sachs, John R., S.J. The Christian Vision of Humanity: Basic Christian Anthropology. Collegeville, MN: Liturgical Press, 1991.

Schillebeeckx, Edward. Christ, The Experience of Jesus as Lord. New York: Seabury Press, 1980.

----Church: The Human Story of God. New York: Crossroad, 1990.

Schillebeeckx, Edward. God, the Future of Man. Translated by N.D. Smith, New York: Sheed \& Ward, 1968.

----.The Understanding of Faith: Interpretation and Criticism. Trans. N.D. Smith; New York; Seabury Press, 1974.

Von Balthasar, Hans Urs. Theo-Drama: Theological Dramatic Theory, Volume IV: The Action. Translated by Graham Harrison. San Francisco: Ignatius Press, 1994.

Wismer, Patricia. "For Women in Pain: A Feminist Theology of Suffering," In In the Embrace of God. Edited by Ann O’ Hara Graff. Maryknoll, NY: Orbis, 1995. 